\title{
SPORT AND PRESS IN THE PORTUGUESE COLONIES IN AFRICA - \\ ORIGINS AND HISTORICAL PERSPECTIVES
}

DESPORTO E IMPRENSA NAS COLÓNIAS POR TUGUESAS EM ÁFRICA -

ORIGENS E PERSPECTIVAS HISTÓRICAS

\section{Francisco Manuel Pinheiro'}

\author{
Recebido em: 03 de março de 2017 \\ Aprovado em: 22 de maio de 2017 \\ Sistema de Avaliação: Double Blind Review \\ RCO | a. 9 | v. 2 | p. 3-15 | jul./dez. 2017
}

\begin{abstract}
This article is a contribution for the African studies, with a main emphasis in the popular culture, sport history and media studies in Angola and Mozambique during the colonial period. The press is a key figure and played a leading role in the emergence and development of sport on the Portuguese colonies in Africa during the twentieth century, especially on its origins and popularization in the 1920s and 1930s. Thinking about this process, on its multiple dimensions, is the main objective of the research, crossing with social impacts and specific characteristics of the colonialism. The article tries to give contributions for several aspects, included the role of local elites, middle class and colons in sport and press asymmetries; the urban context; the football popularity; the clubs power; the local and regional rivalries; or the relations between metropolis and colonies. Multiple dimensions around a cultural and historical phenomenon as is the sport.
\end{abstract}

Keywords: Sport. Press. Portugal. Africa. Colonialism.

\section{RESUMO}

Este artigo é uma contribuição para os estudos sobre África, com ênfase nos campos da cultura popular, história do desporto e estudos da comunicação, em Angola e Moçambique, no período colonial. Um eixo central de análise é a imprensa que desempenhou um papel fulcral na emergência e desenvolvimento do desporto nas colónias portuguesas em África durante o século XX, em especial nas décadas de 20 e 30 . Pensar este processo de surgimento do desporto, a sua popularização e o papel da imprensa, nas suas mais variadas dimensões, é o principal objetivo desta investigação, que cruza diversos aspetos sociais com as próprias especificidades do colonialismo. Apresenta reflexões sobre o papel dos diversos estratos sociais na sua relação com o desporto e a imprensa; o contexto urbano e a sua influência; a popularidade do futebol; o poder simbólico e real dos clubes desportivos; as rivalidades locais e regionais; ou as relações entre a Metrópole (Portugal) e as suas colónias. Múltiplas dimensões à volta do desporto, visto como um fenómeno cultural e histórico a partir do qual é possível fazer uma história de África.

Palavras-chave: Desporto. Imprensa. Portugal. África. Colonialismo.

\section{INTRODUCTION}

The studies of African popular culture were traditionally focus in arts, music, dance, literature, painting, cinema or theatre (WEST, 2012, p. 16). These works show the dynamic's between tradition

\footnotetext{
${ }^{1}$ Doutor em História pela Universidade de Évora (Évora/Portugal). Pesquisador na Fundação para a Ciência e a Tecnologia (Lisboa/Portugal). E-mail: franciscopinheiro72@gmail.com.
} 
and modernity in the African continent, also the influences (or its absence) of the colonialism and political movements (e.g. nationalism, socialism, communism, neoliberalism). However, several areas are frequently ignored by historians and social scientists, as is the case of sport (VIDACS, 2010, p. 42). And like arts or literature, for example, the observation of sport can explain the African social diversity, cultural variety and anthropological characteristics.

In this research, the key issue is the historical analyses of the sport phenomenon in the Portuguese African colonies and the roll of the media (newspapers) in the sport popularization, dissemination and assimilation between native Africans and Portuguese colonists, in the urban context. On its origins, African sport was an urban occurrence (DOMINGOS, 2012, p. 56), alike the newspapers, created/generated/popularized by local elites in the centre ("downtown") of the biggest colonial cities.

This study will identify the beginning of sport popularization in the two major Portuguese colonies in Africa $^{2}$ (Angola and Mozambique) and the origins of the sport press in these colonies - the newspaper should be seen by the McLuhan paradigm: "the medium, that has the message, has his own power and multiply the power of ideas" (DORTIER, 2005, p. 250). Also the sport and press, as objects in this article, required the "analysis of the transformations" proposed by Foucault (2014, p. 27) in its three dimensions (objects, speeches and changes). It will be apply, to the newspapers analysis, the general methods of research in journalism, with three complementary analysis (speech, contend and pragmatic) as proposed in Lago and Benetti (2007). The research will be conducted in Portuguese archives $^{3}$, with large colonial newspapers deposit. Moreover it will be done a brief examination of historical studies about sport in the Portuguese colonies in Africa and the roll of the press in the sport dissemination and popularization, as well as research tool for this kind of studies.

\section{AFRICAN SPORT HISTORY AND PRESS}

In the twenty century the press consolidated into one of the main tools at researchers' disposal for recovering the past, which is obviously even more relevant when studying Africa, where "even the past is unpredictable", as mentioned by the French historian Christine Messiant (2000). As the African past is so unforeseeable, researchers in general and historians in particular use the 'written document' (regarded as a more reliable and sounder source than the oral history) for reconstructing the past or different pasts as defended by Goellner (2004) because can exist more than one sport history, depending from the theoretical method and the quality of the sources. Therefore, the newspaper will give us a vision of the past and it has a crucial role in that. It is a diversified memory repertoire of/for a society, in a variety of shapes. In the particular case of sport, the ideas thereof and its progress were largely sustained, during the Portuguese contemporaneity, by the press, which while observing reality also shaped and transformed them through events and campaigns. So, studying the history of sport press is both an exercise of recovering sources and constructing a sport history, likewise a vision of the society itself.

In the case of the Portuguese colonial empire in Africa, two referential academic works can help to understand the scope of sport, where newspapers are often a source for analysis and a repository of memory. In Jogos de Identidade - O Esporte em Cabo Verde (Identity games - Sports in Cape Verde), the Brazilian historian Victor Andrade de Melo frequently resorts to local newspapers to reconstruct

\footnotetext{
${ }^{2}$ The Portuguese colonial empire in Africa was formed by Angola, Mozambique, Cape Verde, Guiné-Bissau and São Tomé and Príncipe.

${ }^{3}$ National Library in Lisbon, Hemeroteca of Lisbon, Public Library of Porto (BPMP), General Library of University of Coimbra (BGUC).
} 
sport narratives. The pages of the newspaper Eco de Cabo Verde (1934) are explored, as well as the sport section of the O Notícias de Cabo Verde (1931) and the first sport newspaper of Cape Verde, Goal, founded in 1944, which was focused on "publishing reports on football championships" (MELO, 2011, p. 139), during its ten weekly issues. Melo also turned to the newspaper Boletim dos Falcões de Cabo Verde for studying and characterising the Cape Verde sport movement (known as the Sokols/Hawks) in the 1930s. And for a more enlightened view of the sport movement in Cape Verde, during the postindependence period (in the second half of the 1970s), the Brazilian historian studied four others newspapers: Alerta, Novo Jornal de Cabo Verde, Voz Di Povo and Terra Nova.

Another book with these characteristics is Futebol e Colonialismo - Corpo e Cultura Popular em Moçambique (Football and colonialism - Body and popular culture in Mozambique), by the sociologist Nuno Domingos, published in 2012. It used newspapers as main source of research to understand the African sport movement in Mozambique. This publication is consecrated to "football and the way it was played in Lourenço Marques ${ }^{4}$ - the biggest city and administrative centre of the Portuguese colony of Mozambique - in the first half of the 20th century" (DOMINGOS, 2012, p. 330). The author often resorts to newspapers for contextualising and recovering part of the history of football and the association movement in Mozambique. Domingos used 21 periodicals, including yearbooks, bulletins and newspapers to conduct his research, including some local publications like Notícias da Tarde (19521969), Notícias de Lourenço Marques (1926-1974), O Brado Africano (1918-1974) and O Eco dos Sports (1938-1956).

Considering the important role of the press by repository of memory and source for reconstructing history (quite visible in the aforementioned works), recovering the history of the sport press also involves an exercise of recovering the sport history in general. In our case, the African sport history. And for his study, Giulianotti (2010) proposed five key dimensions/thematics: a social history of the African sport; creation of ethnics and national identities through sport; neoliberalism influence; government and politic issues; sport, development and peace in the African context. Our study is a contribution for several of these dimensions, especially to the construction of a social history of sport in Africa. Likewise the study Mais do que um jogo: o esporte e o continente africano (More than a game: sport and the African continent), published in 2010, with the contribution of 11 authors, was a major contribution for the social history of sport in Africa.

\section{ORIGINS OF SPORT PRESS IN ANGOLA AND MOZAMBIQUE}

The pioneer sport newspapers emerged in the early 1920s, in the main African urban centres "of the large and potentially wealthy possessions of Angola and Mozambique" (ROSAS, 1998, p. 109). However, it was a late phenomenon when compared with the metropolis (mainland Portugal), where the first sport publications were developed in the last quarter of the nineteen century - since 1875, with the Jornal dos Caçadores, the first sport newspaper published in Portugal (PINHEIRO, 2011, p. 22-23). However, albeit late, it coincided with the golden age of Portuguese sport journalism, precisely in the 1920s, when 168 sport periodicals were founded over a period of a decade (PINHEIRO, 2011, p. 125). One of the first sport newspapers founded in the Portuguese African colonies was the weekly $O$ Sporting, in Luanda (Angola), on Sunday 25 June 1922, with the subtitle "Sports media - The only of its kind in the Province of Angola". In the editorial "Our introduction", on the cover, the editorial officers

\footnotetext{
${ }^{4}$ Maputo (changed name in 1976 from Lourenço Marques to Maputo).
} 
(Fernando de Lemos as director and Paulo Sousa Borges as editor) explained that it was a newspaper created with the purpose of "defending sports and all things related". It also recalled that it had been founded by "half a dozen boys, who have given their best to the cause of sport". O Sporting was indented to set "the guidelines which all others wishing to raise sport in this province, where it is still unfortunately in such a decadent state, would follow". The "decadent state" was due to the fact that sports in Luanda had "no more than half a dozen of supporters", which is why creating a sport newspaper was paramount "to unite the meek energies which have long been lying around" and "to develop new ones, which may do something for the sporting ideal".

While betting on "marketing and disseminating" football, swimming and rowing, O Sporting consecrated its usual four pages to local sports news and events, in particular those lead by three Angolan clubs: Club Naval de Luanda, Sporting Club de Luanda and Sport Progresso. These clubs were in the origin of the Football Championship of Luanda, in 1922. They were composed by middle class workers, essentially "commercial and other junior workers", while the local elite were closer to the Tennis Club - tennis was the elite sport at the time. The $O$ Sporting was closer to the clubs formed by the middle class workers and it was a voice for defending their positions and interests. Because of that, the Tennis Club was high criticised by the newspaper on 2 July 1922 for having received inappropriately money from the Legislative Council for Marketing and Developing Sports in Luanda. For O Sporting the public money should go to help poor clubs, to develop and create better structures, rather than help rich and elitist clubs, like the Tennis Club. This position of the newspaper creates several enemies in the Luanda high society. Despite his lower price and its leading role in Angolan sport, O Sporting was suspended on the following number, on 9 July, therefore lasting only three editions.

With an equally pioneer career, the weekly Semana Desportiva was launched on 7 October 1922 in Lourenço Marques (Mozambique), with Amadeu L. Neves as editor. Composed by eight pages on green paper (format 33x24) and sold for the price of two escudos and fifty cents (expensive in comparison with others newspapers), this periodical was set out to be "the champion of physical culture", filling a "gap"7 which "growing physical activity in Lourenço Marques made increasingly visible" . Unlike the $O$ Sporting, with only a few advertising from the enterprises of Luanda, the Semana Desportiva earned strong support from small businesses in Lorenzo Marques. In the inaugural issue, four pages are advertising ( 49 small ads in total). In the following months, thanks to the continued enhanced support, this Mozambican periodical improved the quality of the paper and printing, and increased the number of pages to 18 on January 1923. News reports were generally diversified (with a focus on football, boxing, rowing, horse riding and motor sports) and broad scoped, combining local news with news from mainland Portugal (in the section "News from Portugal") and abroad (usually drawn from international press: the British The Guardian; or the French Le Journal, among others).

Following the doctrinal line of the sport newspapers in the metropolis (mainland Portugal), Semana Desportiva took as priority "to work for the sporting cause", which meant to "work for the spiritual and physical revival of the fatherland"10. In the editorial of 9 February 1924 it was visibly pleased with the overall setting of Portuguese sport journalism, on which "sports newspapers

\footnotetext{
${ }^{5}$ The Editorial Office. Propaganda e Desenvolvimento do Desporto (Sports marketing and development) (1922, July 2). $O$ Sporting, p. 1.

${ }^{6}$ Neves, A.L. Introito. (1922, October 7). Semana Desportiva, p. 3.

${ }^{7}$ Idem, ibidem.

${ }^{8}$ Idem, ibidem.

${ }^{9}$ Castro, J. Jornalismo e sport. (1923, August 4). Semana Desportiva, p. 3.

${ }^{10}$ Idem, ibidem.
} 
multiplied" 11 and "the sports sections of big Portuguese media bodies gradually grew"12, creating a "strong current" 13 which gave the necessary boost to "sports advertising"14 in Portugal, on a par with "enthusiasm for practising sports" 15 country wide. However, contrary to what was expected, this encouraging setting did not bring readers to collaborate with the editorial office of Semana Desportiva, composed with eight amateur editors, who worked as reporters without any payment. It was an amateur newspaper, with a lack of regular staff - a transversal characteristic of the newspapers at the time. Only the interest and dedication of a few journalists maintain the newspaper alive. It was the case of the chief editor Captain Ismael Mário Jorge, who wrote alone the newspaper in April and May 1924. The newspaper closed in 17 May 1924, after 79 editions of high quality, writing and printing.

Figure 1 - Semana Desportiva, a weekly newspaper, launched on 7 October 1922 in Lourenço Marques (Mozambique)

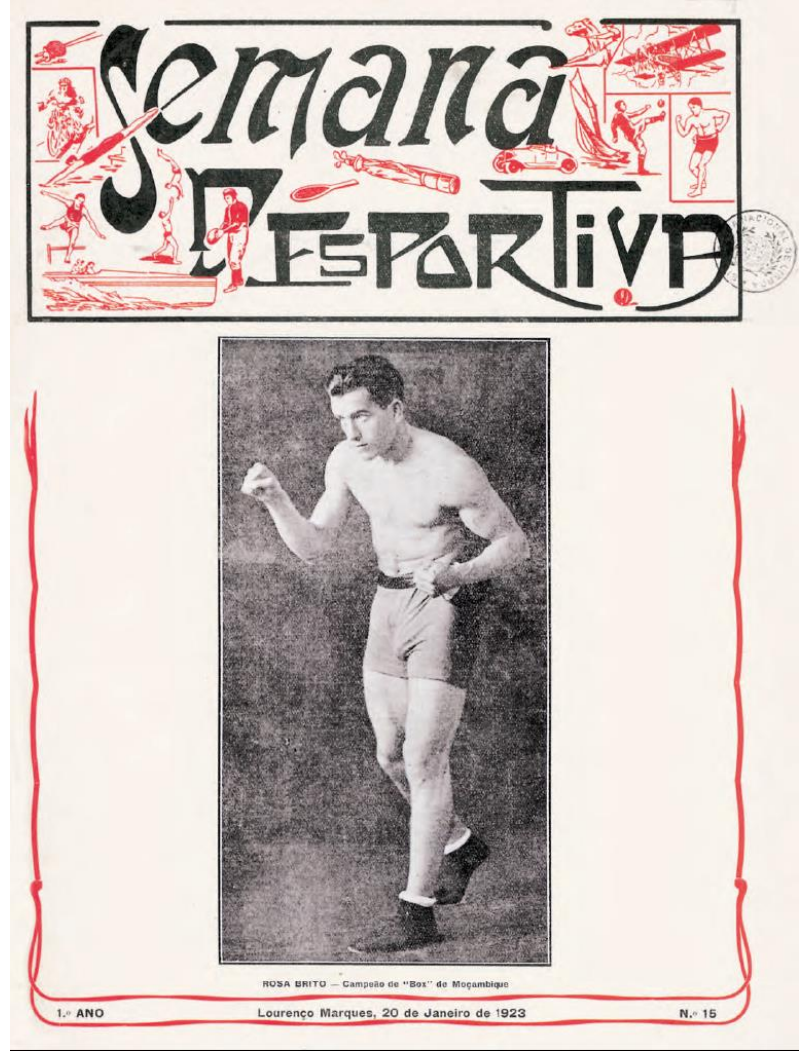

Source: The author

These pioneer sport newspapers of Mozambique (Semana Desportiva) and Angola (O Sporting) opened new horizons and created conditions to the beginning of new periodicals in both countries, as a reflection of the growing popularity of sport in the Portuguese colonies in Africa. The year after $O$ Sporting was founded, in 1923, the monthly magazine Desportos appeared in Luanda (Angola), launched in June, with 36 pages (12 with advertising), sold at the expensive price of five escudos. It was devoted to the major and popular Angolan sports: football, boxing, athletics, rowing, gym, horse riding and tennis. Designed and printed by Tipografia Minerva, in Luanda, Desportos was a magazine warmly welcomed by the sporting community of the Angolan capital. It did not get involved with "clubs and

\footnotetext{
${ }^{11}$ R.M. Para ponderar. (1924, February 9). Semana Desportiva, p. 3.

${ }^{12}$ Idem, ibidem.

${ }^{13}$ Idem, ibidem.

${ }^{14}$ Idem, ibidem.

${ }^{15}$ Idem, ibidem.
} 
chicanery"16 and played the part of an "impartial sports magazine with no favourites"17, as describe in the first edition. The daily newspapers Jornal de Benguela and A Província de Angola gave positive reviews of this magazine in their sports sections. They all joined forces to promote the sporting cause in Angola and fight against "the dangerous microbe of sports: clubs"18 and its rivalries. With José Maria de Carvalho as chief editor, Desportos closed in January 1924, although continuing to be published as a supplement until 17 April 1924 - this last issue was consecrated to the visit to Luanda of the boxer Rosa Brito, the Portuguese middleweight champion (Figure 1).

\section{CONSOLIDATING AN IDEA OF SPORT}

In the 1920s, the idea of sport expanded gradually to Angola and Mozambique. However, sport activity was largely confined to football. It was mostly played by Portuguese sportsmen (white population) who had migrated and some local youth men, usually descendants of Portuguese citizens from the metropolis - the 'white elite'. They are the only ones with leisure time, rules knowledge of sports and money to buy balls and equipment's. At the time, the black population was away from sport and leisure activities.

The sport grows in the African society in late 1920s, especially around the most popular sport: football. This interest permits merging new sport newspapers in the colonies. On 15 August 1929 the bimonthly Angolana - Turismo e Desporto was launched and it was dedicated, as suggested in the subtitle, to promote tourism and sport in Angola. The chief editor was Eduardo Castro, a civil servant (integrates the white middle class). With head office in Luanda, Angolana clearly revealed its sporting vocation, pushing tourism aside - the first cover story was the third pedestrian tour, held in Luanda by the Club Sportivo Nun'Alvares on 21 July. At the beginning, one of its major problems was the distribution. The newspaper could only be bought at his headquarters or at little street shops in Luanda. It chose, at the beginning, to not have subscriptions, to avoid a premature ended - usually the subscribers didn't pay. Only after eight numbers did it start collecting subscriptions, on 1 January 1930. At the time it has an analysis of the firsts months of activity and enlightened readers about the challenges involved to publish a sport newspaper in Angola, which included "the cost of paper and printing" 19 as well as "frequent lack of good will to publish the newspaper"20, which "almost made the Editor give up" 21 Another weakness detected was the lack of newspaper sellers, like the ones in Portugal (young street sellers), capable of popularising a newspaper "with their deafening strong voices, audible at the edge of the neighbourhoods, streets and cafés." 22 Although these difficulties, Angolana managed to continue publishing a few months more, ended on 5 October 1930 after 32 editions (Figure 2).

\footnotetext{
${ }^{16}$ A Redação. Our Team. (1923, October). Desportos, p. 3.

${ }^{17}$ Idem, ibidem.

${ }^{18}$ A Redação. Opinião da Imprensa - Jornal de Benguela. (1923, October). Desportos, p. 3.

${ }^{19}$ A Redação. Temos que existir. (1930, January 1). Desportos, p. 1.

${ }^{20}$ Idem, ibidem.

${ }^{21}$ Idem, ibidem.

${ }^{22}$ Idem, ibidem.
} 
Figure 2 - On 15 August 1929 the bimonthly Angolana - Turismo e Desporto (Luanda) was launched to promote tourism and sport in Angola

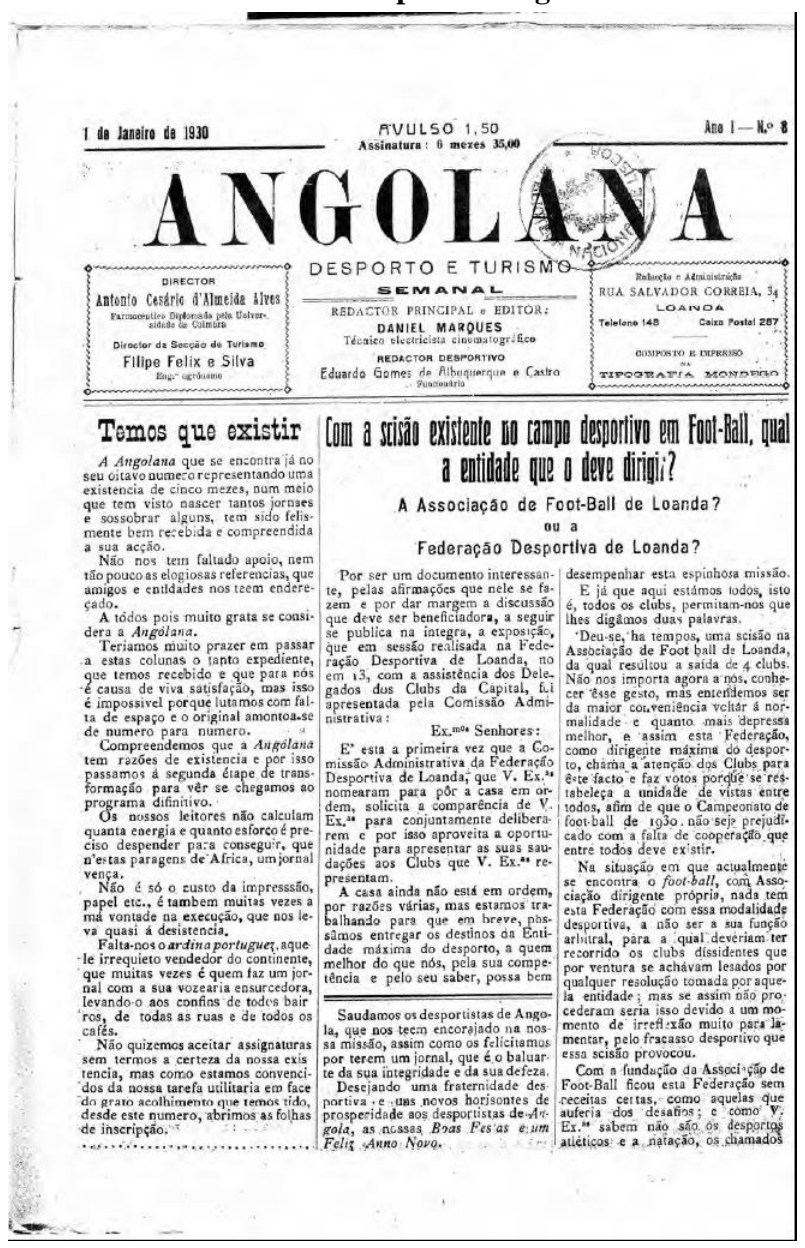

Source: The author

Exactly when Angolana closed, the weekly Angola Desportiva was taking the first steps. It took to the streets of Luanda on 8 August 1930 (Figure 3), supported by four personalities: Agostinho Carvalho (director and pharmacist), Manuel Fernandes (chief editor), Álvaro Carneiro (secretary at the editorial office) and Caetano Almeida (manager and owner). In the editorial "Our newspaper", published on the cover of the inaugural issue, the director board informed readers that in Angola a sport newspaper is very needed to "defending all kinds of sports" and also needed to be a "vigilant sentinel and moralising entity of the city of Luanda and all centres of the Province, where some action is taken to promote sports". Since there was a lack of sporting newspapers, "not react to such inactivity was implicitly condemning provincial sports, particularly in Luanda, to failure, to a certain death". The inaugural issue of Angola Desportiva, with eight pages, was packed with news of the Luanda Football Championship of 1931. Football was also the major subject in the section "Page of the South", responsibility of the correspondent in the province of Benguela, in the south of Angola. Moreover important in the first number of the Angola Desportiva was a brief note at page five, called "Press", where the editorial board gave a special greetings to the newspapers which had inspired it. Three renowned newspapers are mentioned: A Província de Angola 23 ("the oldest newspaper in Luanda"), Jornal de Benguela ("the colonies doyen") and Os Sports ("our counterpart in the metropolis", from Lisbon). The latter one, Os

${ }^{23}$ In the mid 1930s it included an excellent sports section, directed by Alberto Pinto Fernandes, the doyen of sports journalists in Angola. 
Sports, was mentioned in the editorial "Clashes" on 3 October 1931 as the best example of what a sport newspaper should be (a model to follow - a model from the mainland). The same editorial regretted the "slandering" to which it was being subjected and appealed to the creation of a "family" among Angolan sportsmen, capable of "being respected and regarded, not as a gang of gossips as until now, but as a nucleus of high and noble aspirations, fighting for the resurgence of the race".

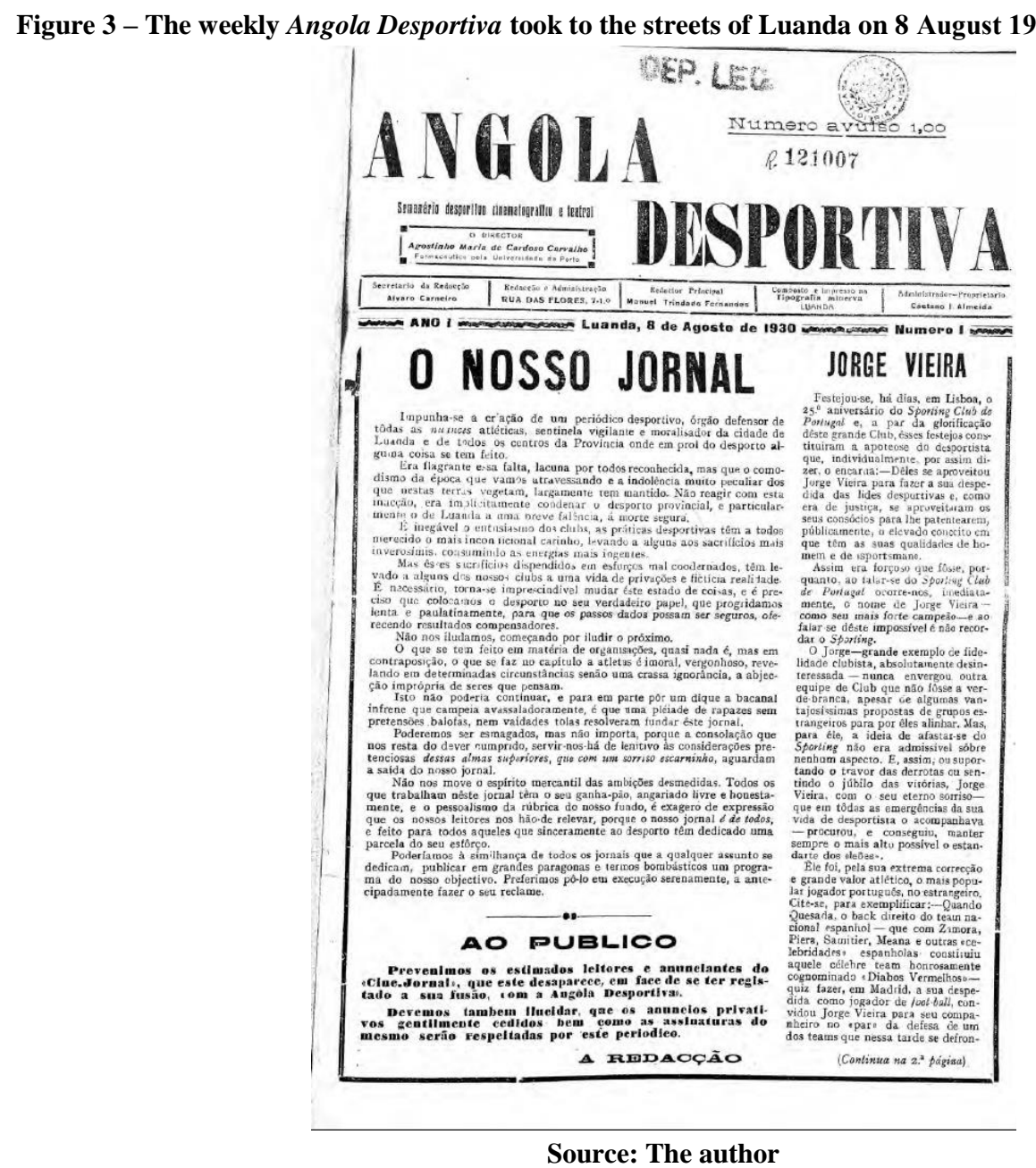

The dream of creating a large sporting family was not fulfilled, which did not prevent the Angola Desportiva from continuing to be published throughout the decade of the 1930s. Every anniversary issue, published annually in the middle of August, was consecrated to deep thinking about Angolan sport and generally revealing enormous disappointment. "We feel sick with disappointment" was the expression written in the editorial celebrating the second anniversary, on 29 August 1933. However, this was backed by tremendous determination in "fighting for the bright future of Angolan sport" - words written in the same editorial.

The tenacity of Angola Desportiva was rewarded by the growing support that received from the Angolan sportive community. Some major names of the Angolan sport journalism were attracted to collaborate with the newspaper, like Eduardo Castelbranco, who became executive director and editor of the newspaper for many years. The newspaper and the director became so intimately related that when 
Castelbranco died, in mid-September 1971, the Angola Desportiva closed, on 29 September $1971^{24}$ this last number was dedicated to the death of Eduardo Castelbranco. From 1930 to 1971, the Angola Desportiva published 847 numbers and became a referential source to construct the sport history of Angola in the twentieth century.

\section{ENHANCING NATIONAL SPIRIT THROUGH SPORT}

In the early 1930s, although Angola Desportiva has some editorial leadership in Luanda, this did not avoid new attempts to implement other sport newspapers in the city or country. One attempt arose in September 1932, conducted by a group of young sport enthusiasts (lead by Armando Ferreira). They launched the bimonthly Desportine - Desporto e Cinema, which lasted until 15 September 1933, in a total of 16 issues consecrated mostly to Angolan football and football in the metropolis, especially Lisbon. Another attempt was O Sport de Mossâmedes, published from 15 August 1931 to 26 August 1932, who "fought bravely for the development of physical education in Southern Angola"25. Based in the city of Mossâmedes, this "bimonthly newspaper for the publicity of physical education" (it was the subtitle) had three different directors: beginning with António Mendes (who had a university degree in "Pharmacy by the Lisbon School of Medical and Surgical Studies", as stated in the newspaper header ${ }^{26}$ ); followed by Pedro Madeira ("Doctor of Medicine and Surgery by Lisbon University"27); and Torres Garcia ("Bachelor by University of Coimbra"" 28 ) - all of them Portuguese colons, members of the (white) elite. The usually four pages of the newspaper were filled with football and basketball local news, as well as some news reports from Lisbon, based on articles published in Lisbon newspapers like Notícias Ilustrado (weekly magazine), Diário de Notícias (daily newspaper) or $O$ Volante (weekly motor sport magazine).

The ties with the metropolis were also highlighted in the bimonthly Eco do Sport, published for the first time on 1 January 1932 (Figure 4), in Benguela (Angola), with José Almeida Cota (law bachelor) as director. In the editorial "Our mission", the director explains the intentions of the newspaper: "help boost the spirit and the moral of the Portuguese youth". However, its efforts did not extend beyond four editions and ended on 21 February 1932, in an issue which introduced two deep thoughts (in the articles "Idealisation" and "Comments") about the context of sport in Benguela and mostly across Angola. The newspaper regretted the ongoing "hatreds between clubs" 29 , the "interclub fighting" ${ }^{30}$ and the fact that football sucked up all of the attention of youth in Benguela "in maddening blindness which regrettably drew them away from other sports" ${ }^{\prime 3}$.

\footnotetext{
${ }^{24}$ The header of Angola Desportiva included very illustrative sub-titles: "Do desporto para o desporto"; "Fundado em 1930 O mais antigo da especialidade em todo o território Português e único em todo o Continente Africano"; "Semanário independente ao serviço do Desporto" (From sport for sport; Founded in 1930 - The oldest in its field on Portuguese territory and the only on the whole African continent; Independent weekly at the service of Sports).

${ }^{25}$ A Redação. À guisa de Prodromo... (1931, August 15). O Sport de Mossâmedes, p. 1.

${ }^{26}$ See issue of 15 August 1931, p. 1.

${ }^{27}$ See issue of 15 February 1932, p. 1.

${ }^{28}$ See issue of 26 August 1932, p. 1.

${ }^{29}$ Neves, M. Idealizando (1932, February 21). Eco do Sport, p. 1.

${ }^{30}$ Idem, ibidem.

${ }^{31}$ A Redação. Comentários. (1932, February 21). Eco do Sport, p. 1.
} 
Figure 4 - The bimonthly Eco do Sport began on 1 January 1932, in Benguela (Angola), to "help boost the spirit and the moral of the Portuguese youth"

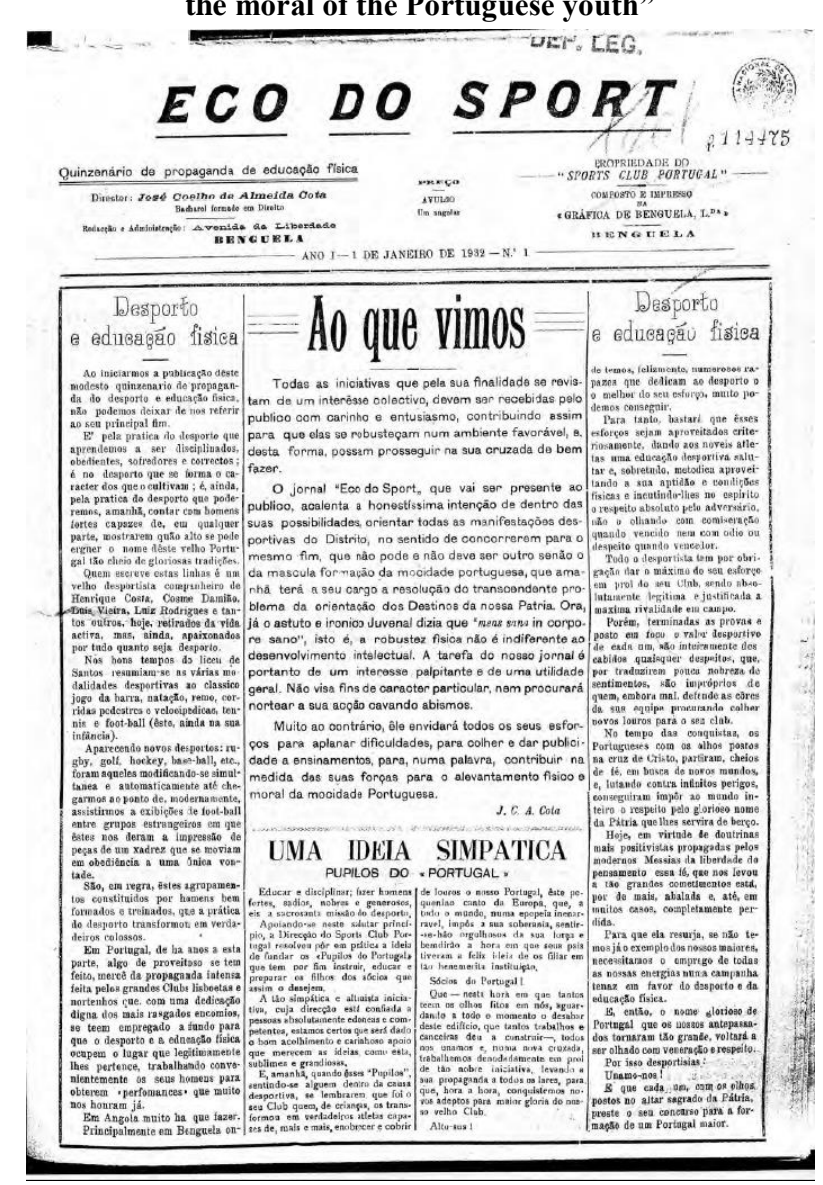

Source: The author

\section{FOOTBALL RIVALRIES EFFECTS}

One of the few positive effects of the rivalries between clubs in Angola was the creation of several bulletins by the clubs. They try to report their own views about the sporting events and fight their adversaries, thereby creating a link between the club, fans and general public. In August 1931, the Atlético Club de Mossâmedes decided to launch $O$ Atlético, a monthly bulletin directed by Torres Garcia (bachelor by University of Coimbra, Portugal), with the headquarters in the city of Mossâmedes, Angola. This newspaper was also "Targeted by the Censorship Committee", created after the imposition of a Dictatorial regime in Portugal in 28 May 1926. The bulletin $O$ Atlético combined local and national news with information from the metropolis and international notices - it was published five times, until 25 December 1931.

In the following years, more clubs in Angola created their own bulletins. Some were annual, like Sport Lubango e Benfica (Lubango, 1932-1949), or celebrates some sport event. Others combined news of their club with more eclectic and general information, like the biweekly $O$ Desporto $^{32}$ (Luanda, 1934),

\footnotetext{
${ }^{32}$ Released for the first time on 1 March 1934, under the director Armando Ferreira, it included four pages with the local news, and news from mainland Portugal and abroad, quite broad-scoped (covering several disciplines of sport) and high quality (good feature articles and in depth analyses of the overall sport movement). The second issue, released on 7 May 1934, changed its name to Os Desportos (there had been a newspaper in Benguela called $O$ Desporto, so they could not use the same name). It lasted only until issue no. 8//9 of 8 September 1934.
} 
belonging to Sport Lisboa e Luanda (Figure 5) and the monthly Boletim do Sporting Club de Luanda ${ }^{33}$ (Luanda, 1936-1957). Both clubs are colonial extensions from the most popular clubs in the metropolis capital: Sport Lisboa e Benfica and Sporting Clube de Portugal. In a way, the rivalries from the metropolis football contaminate the colonial football and clubs relations.

Figure 5 - The biweekly $O$ Desporto (Luanda, 1934) combined news of their club (Sport Lisboa e Luanda) with more eclectic and generalist information

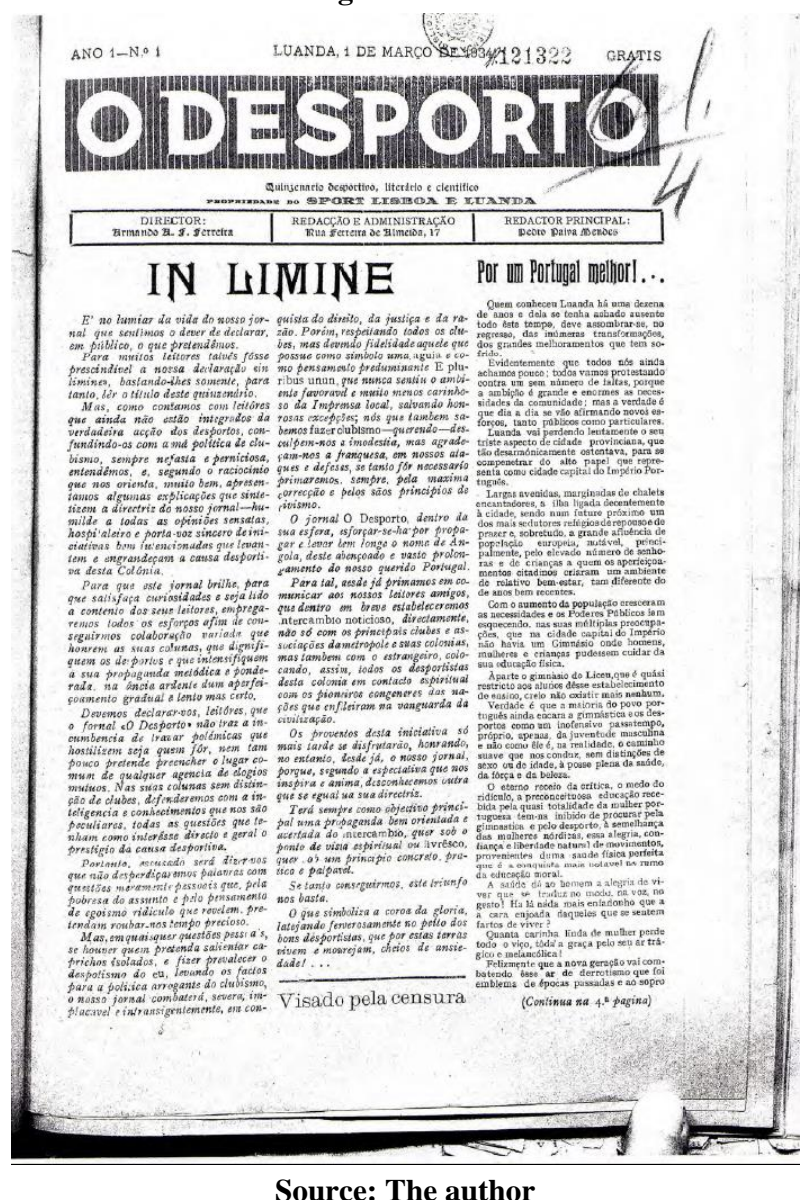

In the late 1930s, most of the clubs bulletins were published only on special occasions, like Sport Lisboa e Luanda ${ }^{34}$ (Angola, 1937), Boletim do Sporting Club Quelimane (Mozambique, 1938) and Sport Lisboa e Bolama ${ }^{35}$ (Guiné, 1938). The only club bulletin with longevity was $O$ Desportivo, presented on 3 September 1938, with a special edition celebrating the opening of the headquarters of Grupo Desportivo de Lourenço Marques, from Mozambique, with the doctor Abel de Carvalho as director and editor. Other editions of $O$ Desportivo were published on special dates of the club ${ }^{36}$, but towards the end of the 1950s it began to be released regularly, once a month, until December 1961 (36 issues in total).

In terms of general news, the only sport newspaper published during this period was Eco dos Sports, launched in Lourenço Marques (Mozambique) on 10 May 1938, with 218 editions published

\footnotetext{
${ }^{33}$ Owned by Sporting Club de Luanda, 3rd subsidiary (the 1st in Africa of Sporting Clube de Portugal), this bulletin was first released in August of 1936, under the director Fernando Sá, with irregular publications until issue 31, in October 1944 (after which it was only released on the occasions of the club's anniversary and in important moments, like when the President of the Republic, Craveiro Lopes, visited Luanda, on 21 June 1953, and a special edition was published). In March 1957 it re-emerged as a monthly periodical, but released only once more in April-May 1957.

${ }^{34}$ A commemorative issue on the occasion of the 25th anniversary, published in October 1937.

${ }^{35}$ Single issue, published in November 1938.

${ }^{36}$ E.g. in August 1945, to celebrate the 24th anniversary.
} 
until 4 August 1958. Besides this generalist sport newspaper, the sport journalism in the Portuguese African colonies was enhanced with the inception of a specialised sport newspaper, the monthly Asas, dedicated to sportive aviation and published in Luanda (Angola) between September and December 1938.

\section{FINAL CONSIDERATIONS}

The advent of the sport press in the Portuguese African colonies emerged in the 1920s, influenced by local elites and Portuguese migrants from the metropolis (especially from the two major cities, Lisbon and Porto). These colons and/or migrants had a previous contact with several sports in Portugal, namely football, tennis, box, cycling or motor sports, for example. Consequently, they had the necessary knowledge (rules and infrastructures) for implementing different sports in the colonies, aggregating around them the local community. Gradually, the process of developing social sportive activities in the Portuguese colonies grew through the clubs, in particular driven by the football popularity. The sport press provided a strong boost to the process and grew too. It took two major functions: organising sport events and disseminating information about those sport events. Besides it was the same strategy used by the sport press in the metropolis during the 1900s and 1910s. The same happen in the Portuguese colonies in Africa in the 1920s.

The sport and press were dominate, in the speeches and practices, by the elite and the middle class, traditionally white, masculine and literate, with frequency of high education in the metropolis. Sport appears as an elitist practice, far away from the poor's and lower working classes (for extension the black population), but it isn't a close process, with different repercussions and effects in the black population and in the public space, with cultural transfers between the centre and the periphery of biggest cities (see DOMINGOS, 2012, p. 221). Other aspect was the fact that some of the newspapers directors came from the medicine practice, so there vision of sport are directly related with health and hygienist issues. Furthermore their sport vision were from the centre of the cities (the so called downtown) and not from the peripheries (the sport in the suburban areas), with the necessaries asymmetries and ambivalences.

This article, as explain at the beginning, is a contribution for the discussion and knowledge about the sport history in Africa during the colonial period, crossing the African sport press roll and its own history. The sport history in Africa is an open field for social and human scientists, with large space to develop new and innovative research about others African countries with similar or divergent historical, political or cultural trajectories - to promote comparative studies between African countries and between the African continent and others regions of the world. Independent from the topic - should be continued the development of sport research related with gender, development, public space, international relations, athletics migrations, economic impact, for example-, the new studies on African sport needed a deep historical contextualization and put sport as a major and serious topic to understand the social and contemporary history of Africa. Besides needed a more closing work between African and nonAfrican academics, to reinforce the sport studies about this continent and produce more relevant studies for the general understanding of Africa.

\section{REFERENCES}

ALEXANDRE, V. Velho Brasil, Novas Áfricas - Portugal e o Império (1808-1975). Porto: Edições Afrontamento, 2000. 
CABRAL, J. P. Existe uma cultura portuguesa? In: JORGE, V. O.; SILVA, A. S. (Org.). Existe uma cultura portuguesa? Lisboa: Difel, 1993, p. 123-162.

COELhO, J. N. \& PINHEIRO, F. A Paixão do Povo: História do Futebol em Portugal. Porto: Edições Afrontamento, 2002.

DOMINGOS, N. Futebol e Colonialismo - Corpo e Cultura Popular em Moçambique. Lisboa: ICS, 2012.

DORTIER, Jean-François (Org.). Une Histoire des Sciences Humaines. Paris: Sciences Humaines Éditions, 2005.

ESTRELA, A. (1980). História da Educação Física. In: SÉRGIO, M.; FEIO, N. (Org.). Homo Ludicus - Antologia de textos desportivos da cultura portuguesa. Lisboa: Compendium, 1980, p. 73-77.

FEIO, N. Portugal: Desporto e Sociedade. Lisboa: Direção-Geral da Comunicação Social, 1985.

FOUCAULT, M. Las redes del poder. Buenos Aires: Prometeo Libros, 2014.

MELO, V. A. Jogos de identidade: o esporte em Cabo Verde. Rio de Janeiro: Apicuri, 2011.

GOELLNER, S. V. Esporte moderno: memória e história. Revista Digital, v. 10, n. 77, p. s/p, 2004.

LAGO, C.; BENETTI, M. (Org.) Metodologia de pesquisa em jornalismo. Rio de Janeiro: Editora Vozes, 2007.

MESSIANT, C. (2000). Em Angola, até o passado é imprevisível. In: AAVV. Construindo o passado angolano: as fontes e a sua interpretação - Atas do II Seminário Internacional sobre a História de Angola, Luanda, 4 a 9 de agosto de 1997. Lisboa: Ed. Comissão Nacional para as Comemorações dos Descobrimentos Portugueses, 2000, p. 803-859.

PIMENTA, F. T. Portugal e o Século XX - Estado-Império e Descolonização (1890-1975). Porto: Edições Afrontamento, 2010.

PINHEIRO, F. História da Imprensa Desportiva em Portugal. Porto: Edições Afrontamento, 2011. ROSÁRIO, A. T. O Desporto em Portugal. Lisboa: Instituto Piaget, 1996.

ROSAS, F. O Estado Novo. In: MATTOSO, J. (Org.). História de Portugal. Lisboa: Editorial Estampa, 1998, v. 7.

VIDACS, B. O esporte e os estudos africanos. In: MELO, V. A., BITTENCOURT, M.; NASCIMENTO, A. (Org.). Mais do que um jogo: o esporte e o continente africano. Rio de Janeiro: Apicuri, 2010, p. 37-69.

WEST, H. G. Prefácio. In: DOMINGOS, N. Futebol e colonialismo - Corpo e cultura popular em Moçambique. Lisboa: ICS, 2012, p. 13-17. 